\title{
High-Solid Systems of Partially Hydrolysed Waxy Maize Starch: Rheological and Structural Characterisations
}

\author{
G. K. Lopes, ${ }^{a}$ E. G. Azero, ${ }^{b}$ M. Vázquez da Silva, ${ }^{c}$ M. P. Gonçalves ${ }^{c}$ and C. T. Andrade ${ }^{*, a}$ \\ ${ }^{a}$ Instituto de Macromoléculas Professora Eloisa Mano, Universidade Federal do Rio de Janeiro, \\ Centro de Tecnologia Bloco J, CP 68525, 21945-970 Rio de Janeiro-RJ, Brazil \\ ${ }^{b}$ Departamento de Ciências Naturais, Escola de Ciências Biológicas e da Saúde, Universidade \\ Federal do Estado do Rio de Janeiro, Avenida Pasteur 458, 22290-240 Rio de Janeiro-RJ, Brazil \\ ${ }^{c}$ Departamento de Engenharia Química, REQUIMTE, Faculdade de Engenharia da Universidade do Porto, \\ Rua Dr. Roberto Frias, 4200-465 Porto, Portugal
}

\begin{abstract}
O comportamento reológico de dispersões com alto teor de sólidos, de misturas de amido de milho ceroso hidrolisado (HWS), em presença do concentrado de proteínas do soro do leite (WPC) e uréia, foi estudado por medidas oscilatórias de pequena amplitude no regime linear, sob aquecimento a $80{ }^{\circ} \mathrm{C}$ e resfriamento a $25^{\circ} \mathrm{C}$, a pH 7,5. A amostra de HWS não-gelificante foi obtida por sonicação de amido de milho ceroso previamente gelatinizado. O fluxo sob cisalhamento contínuo e a microestrutura foram investigados após o resfriamento a $25^{\circ} \mathrm{C}$. As dispersões foram preparadas na razão 1:1 (m/m) WPC/uréia, com concentrações crescentes de HWS. Comportamentos reológicos típicos de sólidos e de líquidos foram observados após resfriar as misturas a baixa temperatura, em função da razão HWS/WPC. Na menor razão HWS/WPC, uma estrutura tixotrópica foi caracterizada sob fluxo contínuo, e visualizada por microscopia óptica sob baixa ampliação como uma rede contínua. Com o aumento da razão HWS/WPC dentro de uma certa faixa, misturas gelificantes e não-gelificantes resultaram em estruturas com separação de fases, as quais não fluíram. Com a razão HWS/WPC mais alta, uma dispersão pseudoplástica foi formada, consistente com o comportamento reológico típico de líquidos sob regime linear, e homogênea, quando visualizada sob microscopia óptica.
\end{abstract}

The rheological behaviour of some high-solid mixed dispersions of partially hydrolysed waxy maize starch (HWS), in the presence of whey protein concentrate (WPC) and urea, was followed by small-amplitude oscillatory measurements in the linear domain, under heating to $80{ }^{\circ} \mathrm{C}$ and cooling to $25^{\circ} \mathrm{C}$, at $\mathrm{pH}$ 7.5. The non-gelling HWS sample was obtained by sonication of previously gelatinised waxy maize starch. Steady-shear flow and microstructure were investigated after cooling to $25^{\circ} \mathrm{C}$. Dispersions were prepared at 1:1 (m/m) WPC/urea ratio, with increasing HWS concentrations. Typical solid- and liquid-like rheological behaviours were observed after quenching the mixtures to low temperature, depending on HWS/WPC ratio. At the lowest HWS/WPC ratio, a thixotropic structure was characterised under steady-shear flow, and visualised by light microscopy at low magnification as a continuous network. With increasing HWS/WPC ratio within a certain range, gelling and non-gelling mixtures resulted in phase-separated structures, which hindered viscous flow. At the highest HWS/WPC ratio, a shear-thinning dispersion was formed, consistent with the liquid-like small deformation properties and the homogeneous image obtained by light microscopy.

Keywords: viscoelastic behaviour, steady shear flow, light microscopy, sonicated waxy maize starch, whey protein concentrate, urea

\section{Introduction}

Due to low cost, starch has been used in the manufacture of several products. Native regular starches

*e-mail: ctandrade@ima.ufrj.br are found as semi-crystalline granules, composed of essentially linear amylose and highly branched amylopectin, and characterized by properties that limit their commercial applications. Depending on the application, genetic modifications, which lead to higher contents of amylose or practically no amylose, are 
preferred. Usefulness of starches is still expanded by chemical or physical modifications. Although high molecular weight starches may give strong films, the viscosity of these starches is also high, and only low-solid dispersions can be handled. Modified starches, which yield "pumpable" dispersions at relatively high solids are generally preferred.

Non-traditional physical methods, such as sonication, ${ }^{1}$ have received attention in synthesis because they are considered environmentally friendly methods. Exposing a polymer solution to high intensity ultrasonic radiation has as primary effect the reduction of molecular weight. The process is known to be nonrandom, and cleavage occurs preferentially near the middle of the chain, without altering the chemical structure of the repeating unit. ${ }^{2,3}$ Sonochemical effects are largely attributed to phenomena that result from cavitation, which consists in the growth and very rapid collapse of micro-bubbles formed by high intensity acoustic waves propagating through the solution. ${ }^{1}$ Particularly for starch, the molecular weight of its components has significant influence on many properties, among them water absorption and solubility, gelation and retrogradation.

In certain cases, blending starch with other synthetic or natural macromolecules can improve mechanical and water-binding properties. Addition of low molecular weight substances is generally used to adjust formulations and impart suitable flow properties. Urea, for example, apparently weakens polymer-polymer interactions and is used to reduce solution micro-heterogeneities. ${ }^{4}$

Whey protein concentrates (WPC) and isolates (WPI), by-products from cheese and casein manufacture, have been increasingly used for industrial applications due to their functional properties, gelation being one of the most important of them. Native globular proteins in aqueous systems maintain compact structures stabilised by intramolecular non-covalent interactions and disulphide bonds. Heating above the denaturation temperature of the proteins causes the native globular structure to unfold and expose non-polar segments and sulphydryl groups, initially buried in the interior of the globule..$^{5-7}$ At sufficient high concentrations, three-dimensional network formation may occur via the same forces involved in holding native globular protein structures: intermolecular non-covalent interactions and under certain conditions disulfide bonding.

In the present work, in the frame of a project aiming at developing environmentally friendly adhesives based on low cost materials, a partially hydrolysed waxy maize starch sample (HWS) was selected to be studied in mixtures with WPC and urea. Small-amplitude rheological measurements were used on different compositions of high-solid mixtures of HWS/WPC/urea at $\mathrm{pH}$ 7.5, submitted to heating/cooling treatments. Steady-shear flow and microstructure were investigated at low temperature. High-solid systems, in which polymers and/or co-solutes are added at substantial concentrations, are of industrial interest but, to the authors' knowledge, with the exception of the work of Shim and Mulvaney ${ }^{8}$ on gelation of granular starch/ whey protein systems, no other study on their rheological properties has been reported. The rheological characterisation of such systems is important because it provides fundamental information to assess some of the properties of finished products, such as processability and storage stability.

\section{Experimental}

\section{Materials}

Waxy maize starch was a gift from Corn Products Brazil (São Paulo, Brazil) and contains 2\% amylose, $0.3 \%$ ash. A commercial sample of whey protein concentrate (WPC), Alacen ${ }^{\mathrm{TM}}$ 450, was supplied by Probiótica Produtos Naturais, São Paulo, Brazil. According to the manufacturer, the concentrate contains $82.3 \%$ protein, $3.4 \%$ lactose, $7.5 \%$ fat, and $2.8 \%$ ash. Reagent grade urea and rhodamine B were supplied by Vetec Química Fina (Rio de Janeiro, Brazil) and E. Merck A.G. (Darmstadt, Germany), respectively.

\section{Hydrolysis of waxy maize starch by sonication}

A waxy maize starch dispersion was prepared at $7 \%$ $(\mathrm{m} / \mathrm{m})$ concentration, gelatinised at $90{ }^{\circ} \mathrm{C}$ for $90 \mathrm{~min}$, and submitted to ultra-sound radiation in a $750 \mathrm{~W}$ Cole Parmer Processor (Vernon Hills, USA) at $25{ }^{\circ} \mathrm{C}$ for $15 \mathrm{~min}$. The hydrolysed waxy maize starch (HWS) sample was recovered by precipitation in ethyl alcohol and dried in an oven at $50{ }^{\circ} \mathrm{C}$ for $24 \mathrm{~h}$. The intrinsic viscosities, [ $\eta$ ], in 1 equiv. $\mathrm{L}^{-1} \mathrm{KOH}$ solution at $25^{\circ} \mathrm{C}$, for gelatinised native waxy maize starch, and for the hydrolysed sample, were determined as $1.44 \mathrm{dL} \mathrm{g} \mathrm{g}^{-1}$, and $0.35 \pm 0.02 \mathrm{dL} \mathrm{g}^{-1}$, respectively.

\section{Preparation of dispersions}

High-solid dispersions of HWS, HWS/urea and HWS/WPC/urea at $30 \%(\mathrm{~m} / \mathrm{m})$ total concentration were 
prepared with 1:1 (m/m) WPC/urea ratio. First, HWS solutions were prepared (dry weight basis) under stirring at $80{ }^{\circ} \mathrm{C}$ for $20 \mathrm{~min}$. After cooling to room temperature, WPC (dry weight basis) was added as a powder to the HWS solution, and the resulting dispersion was maintained under gentle stirring, at room temperature, overnight. Sodium azide (5 ppm) was added to avoid bacterial growth. The necessary weight of urea was added, the dispersion was homogenised by gentle stirring for $15 \mathrm{~min}$, and the $\mathrm{pH}$ was adjusted to 7.5 with $1 \mathrm{~mol} \mathrm{~L}^{-1} \mathrm{NaOH}$. The samples were degassed to remove air bubbles before rheological measurements and microscopy observations.

\section{Rheological measurements}

Rheological measurements were carried out in a Carri-Med stress-controlled rheometer CSL50 (Newcastle, UK) fitted with cone-and-plate geometry (cone angle of $2^{\circ}, 4.0 \mathrm{~cm}$ in diameter, gap of $55 \mathrm{~mm}$ ). HWS alone, HWS/urea and HWS/WPC/urea dispersions were covered with a layer of paraffin oil to prevent water evaporation and submitted to a frequency sweep experiment over the $0.2-62.83 \mathrm{rad} \mathrm{s}^{-1}$ range. HWS/urea and HWS/WPC/urea dispersions were submitted to a temperature ramp from 25 to $80{ }^{\circ} \mathrm{C}$ at a rate of $2{ }^{\circ} \mathrm{C}$ $\mathrm{min}^{-1}$, at $6.28 \mathrm{rad} \mathrm{s}^{-1}$. The temperature was maintained at $80{ }^{\circ} \mathrm{C}$ for $2 \mathrm{~h}$, and then a frequency sweep was done over the $0.2-62.83 \mathrm{rad} \mathrm{s}^{-1}$ range. The temperature was decreased from 80 to $25{ }^{\circ} \mathrm{C}$ at a rate of $2{ }^{\circ} \mathrm{C} \min ^{-1}$. After an equilibration period of $30 \mathrm{~min}$ at $25{ }^{\circ} \mathrm{C}$, a frequency sweep was recorded at this temperature over the $0.2-62.83 \mathrm{rad} \mathrm{s}^{-1}$ range. The strain amplitude was maintained at $1 \%$, within the linearity domain of the systems. Subsequently, steady shear flow tests were carried out at $25{ }^{\circ} \mathrm{C}$ by increasing shear rate logarithmically to $200 \mathrm{~s}^{-1}$ (up curve), and then reversing the cycle (down curve).

\section{Light microscopy}

The samples to be analysed by optical microscopy were prepared similarly as described in section 2.3. Rhodamine B ( $2 \mathrm{mg})$ was added to WPC suspensions before stirring overnight. After degassing, drops were poured on a slide, covered with a glass cover slip and hermetically sealed to prevent evaporation. After a heating/cooling treatment similar to that used for the rheological measurements, the samples were allowed to stand for $30 \mathrm{~min}$ before examination in a Carl Zeiss Axioplan 2 light microscope (Götingen, Germany) under direct fluorescence.

\section{Results and Discussion}

Figure 1 shows the mechanical spectrum at $25{ }^{\circ} \mathrm{C}$ obtained for HWS at $30.0 \%(\mathrm{~m} / \mathrm{m})$. For this system, the loss modulus $G^{\prime \prime}(\omega)$ values are higher than the storage modulus $G^{\prime}(\omega)$ values, over the frequency window used in the experiments, which reveals the liquid-like character of the sample at high-solid concentration.

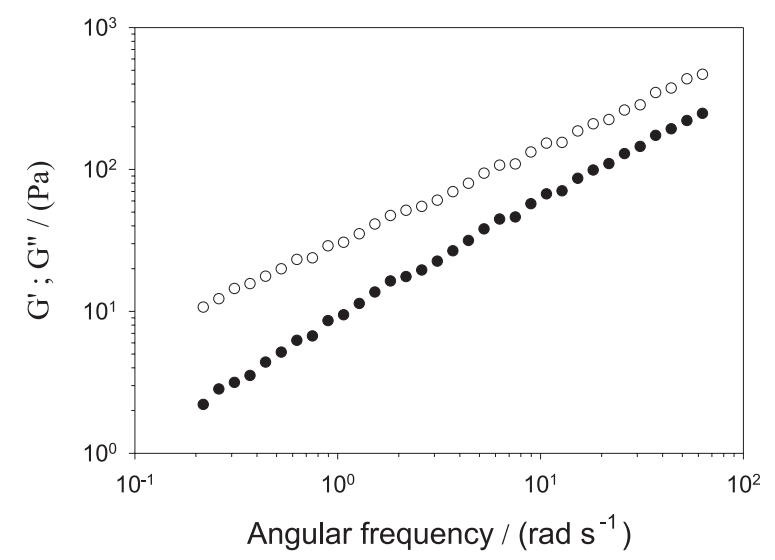

Figure 1. Mechanical spectrum at $25^{\circ} \mathrm{C}$ (1\% strain amplitude) for HWS at $30 \%(\mathrm{~m} / \mathrm{m})$. Filled symbols, storage modulus $\mathrm{G}^{\prime}(\omega)$; empty symbols, loss modulus $\mathrm{G}^{\prime \prime}(\omega)$.

The effect of urea at $3.0 \%(\mathrm{~m} / \mathrm{m})$ on HWS at $27.0 \%$ $(\mathrm{m} / \mathrm{m})$ concentration, as submitted to heating and cooling treatments, was investigated. After obtaining the mechanical spectrum at $25^{\circ} \mathrm{C}$ (Figure 2a), the temperature was raised to $80^{\circ} \mathrm{C}$ (Figure $2 \mathrm{~b}$ ) with a decrease in $\mathrm{G}^{\prime}$ and $\mathrm{G}^{\prime \prime}$ values. The system was stabilized at $80^{\circ} \mathrm{C}$ for $2 \mathrm{~h}$, and cooled back to $25^{\circ} \mathrm{C}$. Although both $\mathrm{G}^{\prime}$ and $\mathrm{G}^{\prime \prime}$ values decreased smoothly by heating, different paths were followed by cooling to $25^{\circ} \mathrm{C}$ (Figure 2c), and the moduli reached much higher values; tenfold larger for the storage modulus G'. However, G'-G" cross-over was not observed during quenching and during the stabilisation period of $2 \mathrm{~h}$ (Figure 2d). During this stabilisation period, the system seemed to have returned to its initial conditions. The mechanical spectrum taken at $25^{\circ} \mathrm{C}$ (Figure 2e) confirms that the HWS/urea system maintained its viscoelastic properties after the heating/cooling treatment. Figures 2a and $2 \mathrm{e}$ are nearly identical.

Figure 3 shows mechanical spectra of HWS/WPC/urea mixtures of varied compositions at $25^{\circ} \mathrm{C}$ before heating. The predominantly viscous character of these mixtures before heating was expected, since whey proteins were in globular conformation. For M1 (12\% HWS + 9\% WPC + $9 \%$ urea), M2 (15\% HWS $+7.5 \%$ WPC $+7.5 \%$ urea), M3 (18\% + 6\% WPC + 6\% urea) and M4 (27\% HWS + $1.5 \%$ WPC $+1.5 \%$ urea) mixtures, $\mathrm{G}^{\prime}(\omega)$ and $\mathrm{G}^{\prime \prime}(\omega)$ 

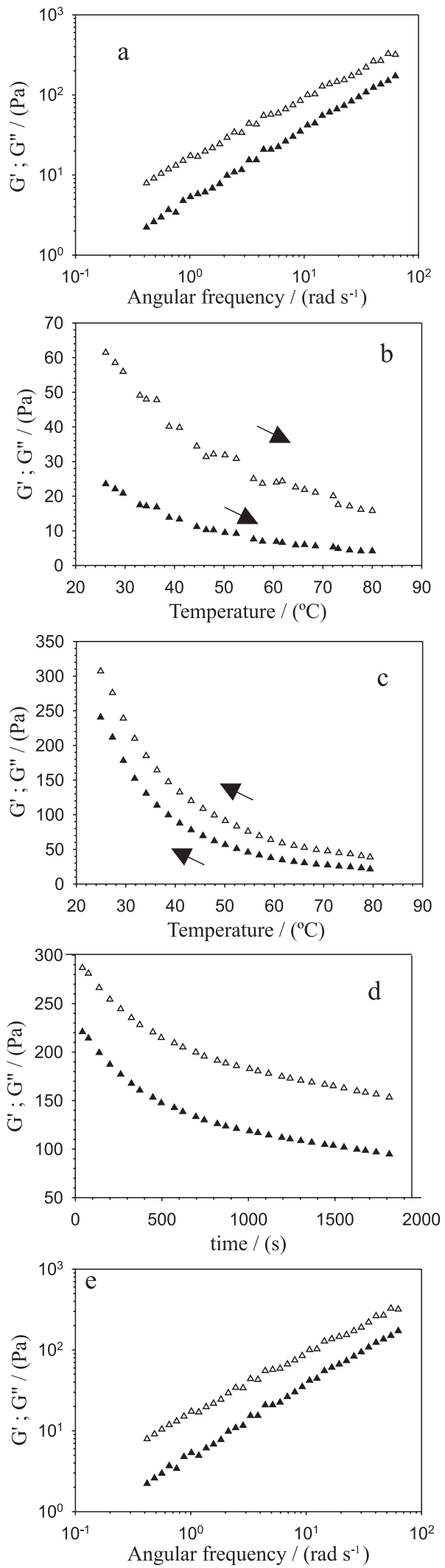

Figure 2. Rheological properties of $27 \% \mathrm{HWS} / 3 \%$ urea system (1\% strain amplitude); (a) mechanical spectrum at $25^{\circ} \mathrm{C}$, (b) temperature ramp from 25 to $80{ }^{\circ} \mathrm{C}$, (c) temperature decrease from 80 to $25^{\circ} \mathrm{C}$, (d) time sweep at $25{ }^{\circ} \mathrm{C}$, (e) second mechanical spectrum at $25^{\circ} \mathrm{C}$. Filled symbols, storage modulus $\mathrm{G}^{\prime}(\omega)$; empty symbols, $\mathrm{G}^{\prime \prime}(\omega)$.
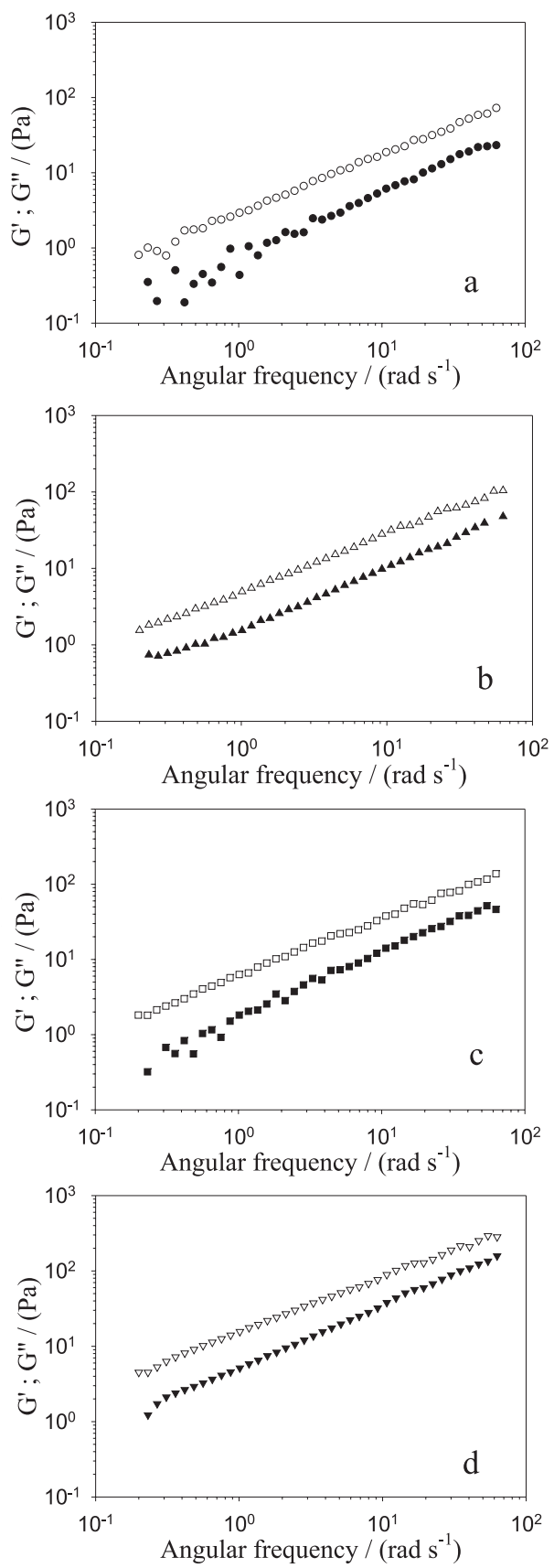

Figure 3. Mechanical spectra of HWS/WPC/urea systems (1\% strain amplitude), at $25^{\circ} \mathrm{C}$, before heating; (a) mixture M1, 12\% HWS $+9 \%$ $\mathrm{WPC}+9 \%$ urea, (b) mixture M2, $15 \% \mathrm{HWS}+7.5 \% \mathrm{WPC}+7.5 \%$ urea, (c) mixture $\mathrm{M} 3,18 \% \mathrm{HWS}+6.0 \% \mathrm{WPC}+6 \%$ urea, (d) mixture M4, $27 \%$ HWS $+1.5 \%$ WPC $+1.5 \%$ urea. Filled symbols, storage modulus $\mathrm{G}^{\prime}(\omega)$; empty symbols, loss modulus $\mathrm{G}^{\prime \prime}(\omega)$.

attained values of similar magnitudes within the frequency range studied.

Submitting the mixtures to an ascending temperature ramp step, network formation could be followed by means of the storage modulus $\mathrm{G}^{\prime}(\omega)$, which would start to increase beyond aggregation and gelation of the whey proteins components, and would equal the loss modulus 
$\mathrm{G}^{\prime \prime}(\omega)$. In the present case, with the exception of mixture M1 (12.0\% HWS + 9.0\% WPC $+9 \%$ urea), with the highest protein and urea concentrations, the G'-G" cross-over was not observed (results not shown). Figure 4 shows the evolution of $\mathrm{G}^{\prime}$ and $\mathrm{G}^{\prime \prime}$, as the systems were heated at $80^{\circ} \mathrm{C}$ for $2 \mathrm{~h}$. Aggregation and gelation occurred in mixture M2 (15.0\% HWS $+7.5 \%$ WPC $+7.5 \%$ urea) during the heating step at $80{ }^{\circ} \mathrm{C}$ (Figure $4 \mathrm{~b}$ ). In Figures $4 \mathrm{c}$ and $4 \mathrm{~d}$, mixtures M3 (18.0\% HWS + 6.0\% WPC + 6.0\% urea) and M4 (27\% HWS + $1.5 \% \mathrm{WPC}+1.5 \%$ urea) maintained the predominantly viscous character, with $\mathrm{G}^{\prime \prime}>\mathrm{G}^{\prime}$ over the frequency window studied. For mixture M1, already gelled during the $25-80{ }^{\circ} \mathrm{C}$ ramp step, $\mathrm{G}^{\prime}$ is still evoluting at the end of the $2 \mathrm{~h}$ curing period. Important variables in gelation of globular proteins are protein concentration, solution $\mathrm{pH}$, temperature, heating time and addition to the system of other components. The concentration threshold for heat-set gelation of $\beta$-lactoglobulin, the main protein in whey and that dominates the overall gelling behaviour, has been reported to be around $1 \%$ $(\mathrm{m} / \mathrm{v})$ near isoelectric conditions. ${ }^{9}$ At low and high $\mathrm{pH}$ values, the higher the ionic strength, the lower the protein concentration required to gel formation. ${ }^{10}$ In the present case, the $\mathrm{pH}$ was increased away from the pI and a whey protein concentrate, rich in mineral salts, was used at sufficiently high concentrations to promote gelation, at least in M1, M2 and M3 mixtures. However, the effect of urea addition should be considered. Urea has no influence on the viscoelasticity of HWS (data not shown), and at low concentrations such as those used in this study, between $1.5 \mathrm{~mol} \mathrm{~L}^{-1}$ (M1) and 0.25 mol L $\mathrm{L}^{-1}(\mathrm{M} 4)$, the main effect of urea has been ascribed to the destabilisation of intermolecular hydrophobic interactions of denatured proteins, ${ }^{11}$ which are the most important non-covalent interaction involved in heat-set gelation of globular proteins at high $\mathrm{pH} .{ }^{12}$ Particularly for mixture M3 (Figure 4c), the time-dependence of the dynamic moduli is characterised by fluctuations, which some authors attributed to bulk phase separation in casein-amylopectin system. ${ }^{13}$ Centrifugation and ageing for some days of mixture M3 did not result in phase separation; however, bulk phase separation was observed after 27 days.

Cooling HWS/WPC/urea systems back to $25{ }^{\circ} \mathrm{C}$ (Figure 5), both G' and G" were increased. This behavior has been observed before for whey protein isolate alone and for protein mixed systems, and attributed to formation of hydrogen bonds, which are favoured at low temperatures. ${ }^{14,15}$ However, the changes depended on HWS/WPC ratio. For M1 (12\% HWS + 9\% WPC +
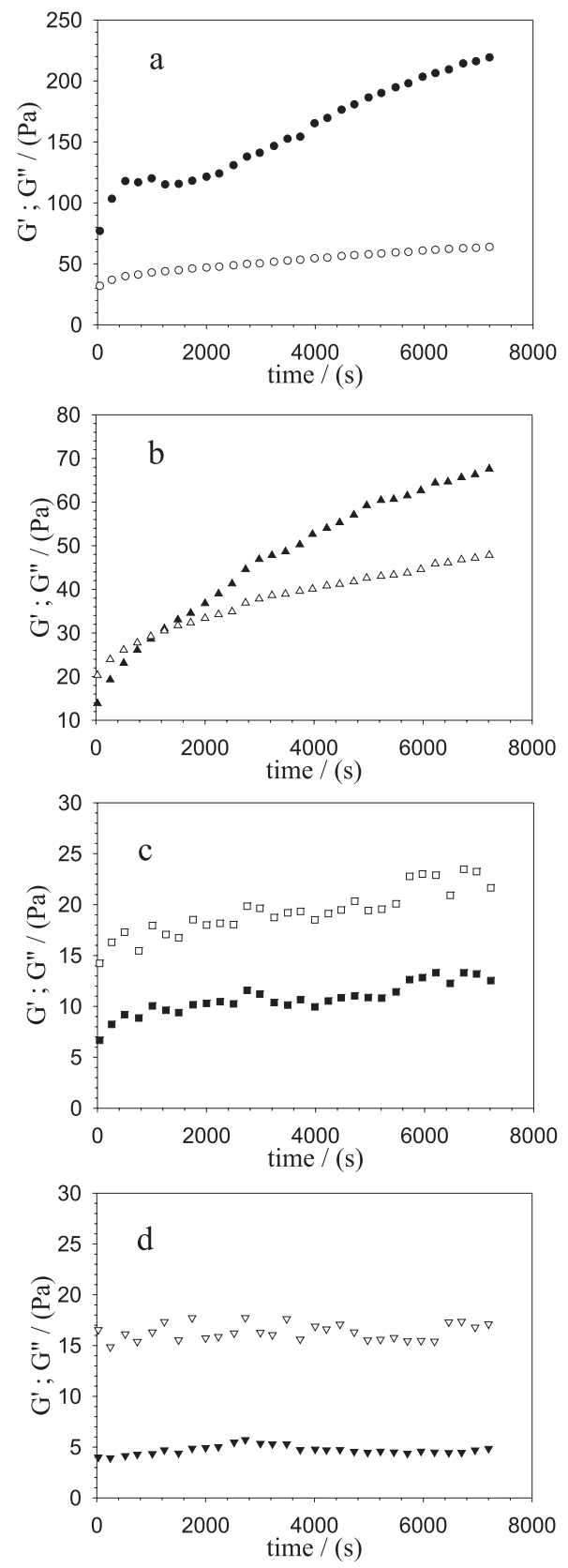

Figure 4. Time sweep of HWS/WPC/urea system at $80{ }^{\circ} \mathrm{C}(1 \%$ strain amplitude, $6.28 \mathrm{rad} \mathrm{s}^{-1}$ ); (a) mixture M1, 12\% HWS + 9\% WPC + 9\% urea, (b) mixture $\mathrm{M} 2,15 \% \mathrm{HWS}+7.5 \% \mathrm{WPC}+7.5 \%$ urea, (c) mixture M3, $18 \%$ HWS $+6.0 \%$ WPC $+6 \%$ urea, (d) mixture M4, 27\% HWS + $1.5 \%$ WPC $+1.5 \%$ urea. Filled symbols, storage modulus $\mathrm{G}^{\prime}(\omega)$; empty symbols, loss modulus $G^{\prime \prime}(\omega)$.

9\% urea), with the lowest HWS/WPC ratio, changes were more significant in $\mathrm{G}^{\prime}$ than in $\mathrm{G}^{\prime \prime}$. As this ratio was increased, changes in $\mathrm{G}^{\prime \prime}$ became more significant. During the short equilibration period at $25^{\circ} \mathrm{C}$, a slight decrease in $\mathrm{G}^{\prime}$ was observed for $\mathrm{M} 1$ and $\mathrm{M} 2$, while for M3 both moduli reached slightly smaller values. No significant evolution of $\mathrm{G}^{\prime}$ and $\mathrm{G}^{\prime \prime}$ was observed for M4 (results not shown). Although correlations between 

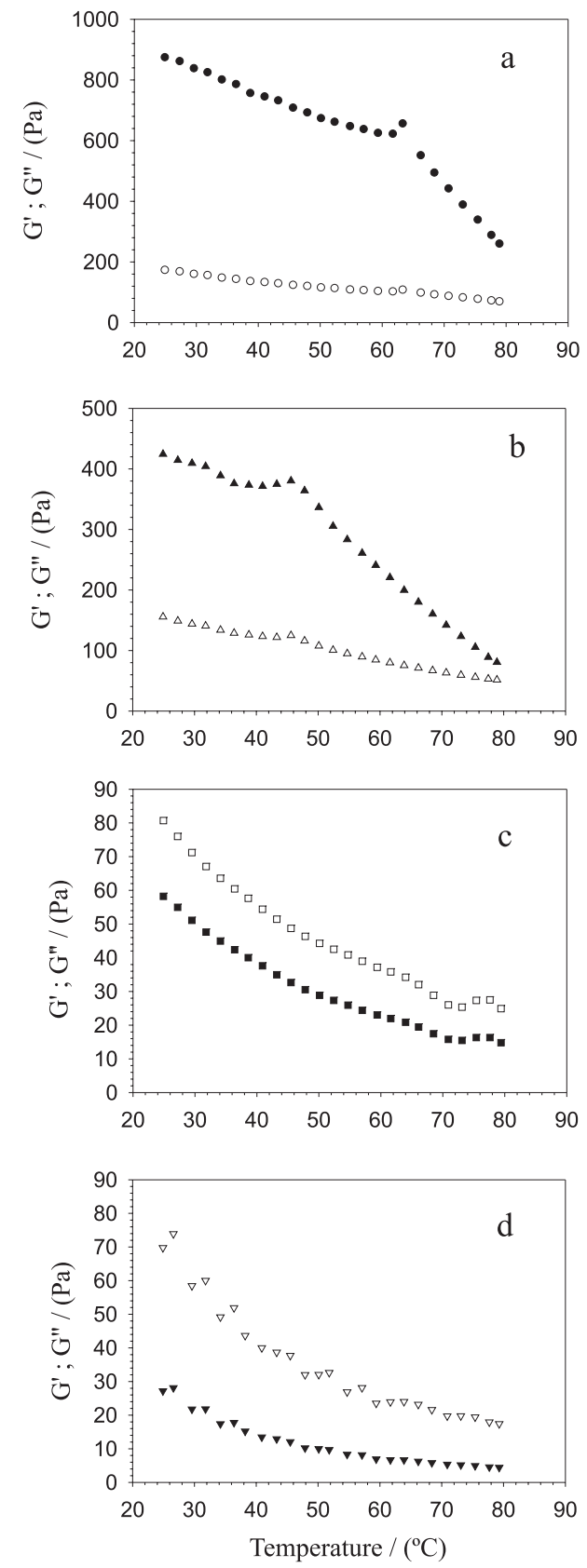

Figure 5. Variation of $\mathrm{G}^{\prime}$ and $\mathrm{G}^{\prime \prime}$ as the temperature is decreased from 80 to $25^{\circ} \mathrm{C}\left(1 \%\right.$ strain amplitude, $\left.6.28 \mathrm{rad} \mathrm{s}^{-1}\right)$; (a) mixture $\mathrm{M} 1,12 \% \mathrm{HWS}+$ $9 \% \mathrm{WPC}+9 \%$ urea, (b) mixture M2, $15 \% \mathrm{HWS}+7.5 \% \mathrm{WPC}+7.5 \%$ urea, (c) mixture M3, $18 \%$ HWS $+6.0 \% \mathrm{WPC}+6 \%$ urea, (d) mixture M4, 27\% HWS $+1.5 \%$ WPC $+1.5 \%$ urea. Filled symbols, storage modulus $\mathrm{G}^{\prime}(\omega)$; empty symbols, loss modulus $\mathrm{G}^{\prime \prime}(\omega)$.

structure and rheological behaviour in mixed systems are complex, in this particular case the differences may reflect at least that the already formed protein network in $\mathrm{M} 1$ and $\mathrm{M} 2$ became more aggregated, and that the predominant viscous character of M3 and M4 was enhanced by quenching.

Mechanical spectra obtained at $25{ }^{\circ} \mathrm{C}$ for HWS/ WPC/urea systems are shown in Figure 6. Solid-like
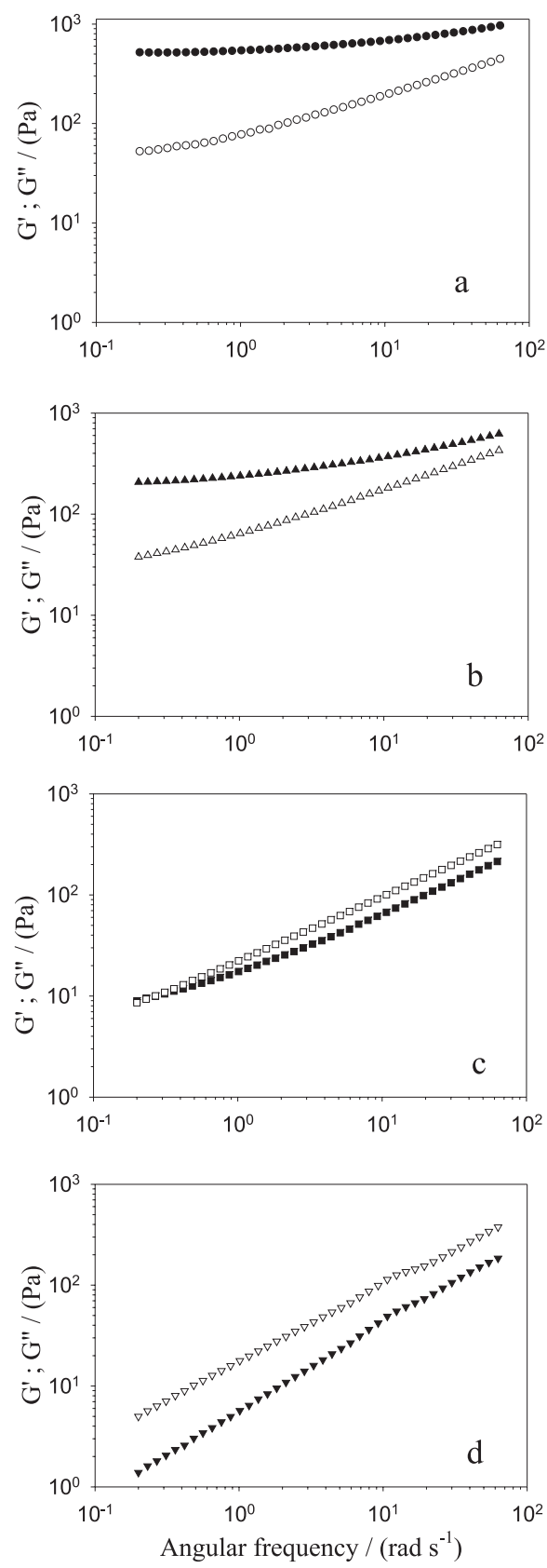

Figure 6. Mechanical spectra of HWS/WPC/urea systems at $25^{\circ} \mathrm{C}$, after cooling from $80{ }^{\circ} \mathrm{C}(1 \%$ strain amplitude); (a) mixture M1, $12 \% \mathrm{HWS}+$ $9 \% \mathrm{WPC}+9 \%$ urea, (b) mixture M2, $15 \% \mathrm{HWS}+7.5 \% \mathrm{WPC}+7.5 \%$ urea, (c) mixture M3, $18 \% \mathrm{HWS}+6.0 \% \mathrm{WPC}+6 \%$ urea, (d) mixture M $4,27 \%$ HWS $+1.5 \%$ WPC $+1.5 \%$ urea. Filled symbols, storage modulus $G^{\prime}(\omega)$; empty symbols, loss modulus $G^{\prime \prime}(\omega)$.

mechanical behaviour can be seen in the entire angular frequency region for mixtures M1 (12\% HWS + 9\% $\mathrm{WPC}+9 \%$ urea) and M2 (15.0\% HWS $+7.5 \%$ WPC $+7.5 \%$ urea). In both systems, $\mathrm{G}^{\prime}$ is slightly frequency dependent, $\tan \delta$ values fall within 0.1 and 1.0 range, and the elastic character decreases slightly as the HWS/ WPC ratio was increased from 1.3 (M1) to 2.0 (M2). An intermediate behaviour ( $\tan \delta$ around 1.0 ) 


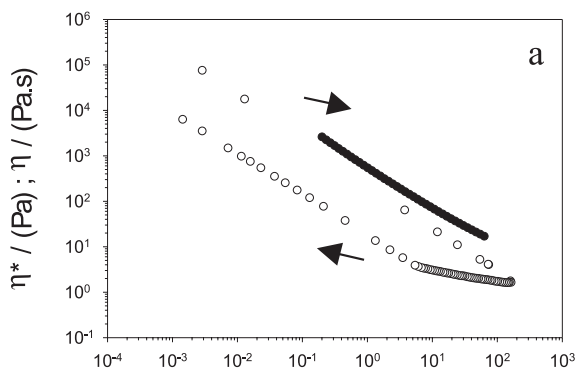

Angular frequency $\left./(\operatorname{rad~s})^{-1}\right) ; \dot{\gamma} /\left(\mathrm{s}^{-1}\right)$

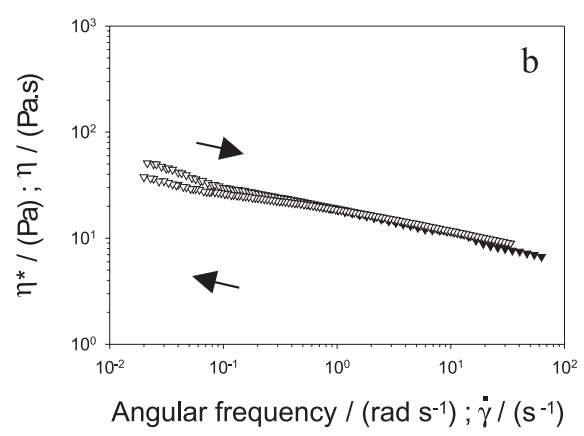

Figure 7. Steady-shear viscosity versus shear rate (empty symbols) and complex viscosity versus angular frequency (filled symbols) for (a) mixture M1, 12\% HWS + 9\% WPC + 9\% urea, (b) mixture M4, 27\% HWS + $1.5 \% \mathrm{WPC}+1.5 \%$ urea.

characterises M3 (18.0\% HWS + 6.0\% WPC $+6.0 \%$ urea), whereas the frequency-dependence of the moduli of mixture M4 (27\% HWS $+1.5 \% \mathrm{WPC}+1.5 \%$ urea) is typically of macromolecular solutions ( $\tan \delta$ values higher than 1.0 and decreasing with frequency).

Steady-shear flow tests were performed on the HWS/ WPC/urea systems, following dynamic experiments. Viscous flow was observed for mixtures M1 and M4. For the other samples, the experiments were interrupted automatically at low shear rates. As can be observed in Figure 7a, M1 gel (12\% HWS + 9\% WPC + 9\% urea) shows a pronounced shear-thinning behaviour, reaching a viscosity near $2 \mathrm{~Pa} . \mathrm{s}$ at the shear rate of $200 \mathrm{~s}^{-1}$. Also, values of the complex viscosity $\eta^{*}$ were larger than those of the steady-shear viscosity $\eta$ at corresponding angular frequencies and shear rates, which means that this system disobeys the empirical Cox-Merz rule, ${ }^{16}$ and suggests that the network is susceptible to large strain under shearing. The down curve is characterised by an initially slow increase in viscosity, followed by a steep but incomplete structure recovery. Thixotropic behaviour was reported for a whey protein isolate gel at $6 \%$ and $\mathrm{pH} 7 .{ }^{15}$ In Figure $7 \mathrm{~b}$, a slight shear thinning behaviour can be observed for M4 (27\% HWS + 1.5\% $\mathrm{WPC}+1.5 \%$ urea). In this case, the Cox-Merz rule ${ }^{16}$ is

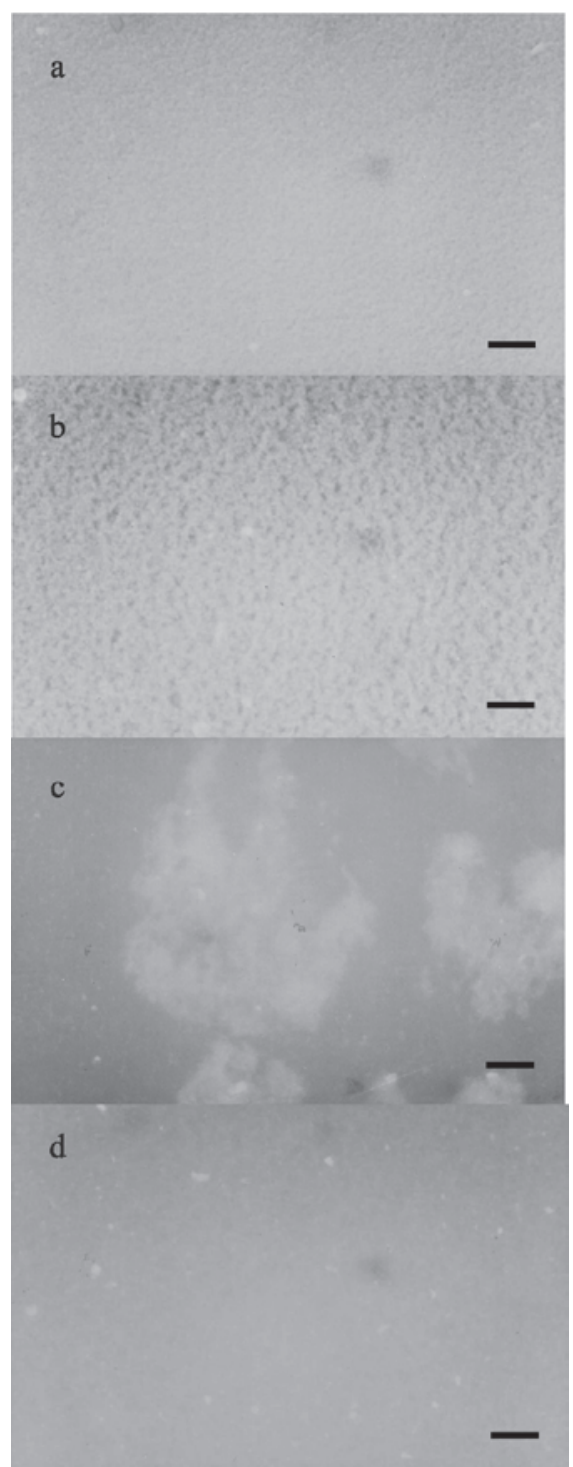

Figure 8. Light micrographs under direct fluorescence of HWS/WPC/ urea systems after heating/cooling treatments; (a) mixture M1, 12\% HWS $+9 \%$ WPC $+9 \%$ urea, (b) mixture M $2,15 \%$ HWS $+7.5 \%$ $\mathrm{WPC}+7.5 \%$ urea, (c) mixture M3, $18 \% \mathrm{HWS}+6.0 \% \mathrm{WPC}+6 \%$ urea, (d) mixture M4 27\% HWS $+1.5 \% \mathrm{WPC}+1.5 \%$ urea. Scale bar $=10 \mathrm{~mm}$.

obeyed, at least over the angular frequency range used to determine $\eta^{*}$.

Light micrographs under direct fluorescence, at 200x magnification, are shown in Figure 8 for HWS/ WPC/urea systems after the heating/cooling treatment. In these micrographs, light and dark regions correspond to protein-rich and protein-depleted phases, respectively. The micrograph of Figure 8 a corresponds to the M1 (12\% HWS + 9\% WPC + 9\% urea) gel, and reveals a homogeneous structure, most probably composed of a continuous protein network that accommodates HWS, representative of a non-phase 
separated system, and consistent with the dynamic and steady-shear flow properties. The micrograph of M4 $(27 \%$ HWS $+1.5 \% \mathrm{WPC}+1.5 \%$ urea $)$ in Figure $8 d$ also reveals a homogeneous system, as expected for a macromolecular dispersion with the rheological characteristics discussed before. Contrarily, M2 (15.0\% HWS $+7.5 \%$ WPC $+7.5 \%$ urea) and M3 (18.0\% $\mathrm{HWS}+6.0 \% \mathrm{WPC}+6.0 \%$ urea) systems have the appearance of protein-aggregated structures. Such structures have been observed before for milk protein/ dextran and milk protein/amylopectin systems, and differ in appearance from emulsion-like microstructures, with protein concentrated in spherical droplets, as observed for milk protein/galactomannans. ${ }^{13}$

In the present case, the difference between M2 and M3 relies on HWS/WPC ratio; in the former, the lower HWS/WPC ratio gave rise to a connected network, whereas for M3 with increasing concentration of HWS, the three-dimensional connectivity was no longer achieved, as reflected in the dynamic experiments.

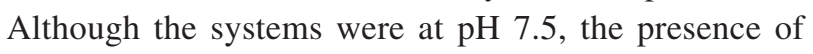
salts in the protein sample led to opaque particulate heatset gels, which allows comparison with a particulate $\beta$-lactoglobulin mixed system ${ }^{17}$ at $\mathrm{pH}$ 5.4. As evidenced by light microscopy, in that study on $\beta$-lactoglobulin and non-gelling amylopectin systems at pH 5.4 and low magnification, protein gel alone presented homogeneous network with small pores between strands of clusters, but the network of mixed systems showed more open structures, with larger pores and clusters, the higher the amylopectin concentration. One might presume that in both M2 and M3 systems, HWS/WPC ratios were high enough to originate large protein clusters or aggregates, connected or not, which probably have contributed to hinder steady-shear flow at low shear rates. Anyway, in both systems, the added concentration of urea was not sufficient to inhibit micro-phase separation.

\section{Conclusions}

Addition of whey protein concentrate and urea to sonicated waxy maize starch affects the rheological and structural characteristics of the resulting high-solid systems submitted to gelling conditions of the protein. This effect depends on the starch/protein concentrate ratio. By heating, the lower the HWS/WPC ratio, the more feasible was the formation of protein network. A homogeneous three-dimensional network, characterised by small deformation rheological measurements and light microscopy, and that presented a shear-thinning and thixotropic behaviour when submitted to steadyshear flow, was formed for the lowest starch/protein concentrate ratio. At intermediate ratios, steady-shear flow was blocked, attributed to large aggregated protein clusters, connected or not, as visualised by light microscopy, and characterised by dynamic measurements. A shear-thinning dispersion with no structure formation was revealed when a high starch/protein concentrate ratio was used. Although rheological and structural properties correlations are in general complex, the association of small deformation and steady-shear rheological measurements with light microscopy supported a common interpretation of data. This is of importance when choosing conditions to prepare mixtures for a certain application.

\section{Acknowledgments}

Corn Products Brazil is acknowledged for supplying the waxy maize starch sample. Daniela S. Alviano is kindly acknowledged for her skilled assistance during microscopy experiments. M. Vázques da Silva is indebted to Fundação para a Ciência e a Tecnologia for the grant $\mathrm{n}^{\circ} \mathrm{SFRH} / \mathrm{BPD} / 11252$ / 2002. The authors thank the financial support from Fundação Universitária José Bonifácio (FUJB), and Conselho Nacional de Desenvolvimento Científico e Tecnológico (CNPq). Coordenação de Aperfeiçoamento de Pessoal de Nível Superior (CAPES), and Gabinete de Relações Internacionais da Ciência e do Ensino Superior (GRICES) are gratefully acknowledged for a CAPES/ GRICES award.

\section{References}

1. Kardos, N.; Luche, J.-L.; Carbohydr. Res. 2001, 332, 115.

2. Price, G. J.; Smith, P. F.; Eur. Polym. J. 1993, 29, 419.

3. Madras, G.; Kumar, S.; Chattopadhyay, S.; Polym. Degrad. Stab. 2000, 69, 73.

4. Braudo, E. E.; Plashchina, I. G.; Semenova, M. G.; Yuryev, V. P.; Food Hydrocolloids 1998, 12, 253.

5. Iametti, S.; Cairoli, S.; De Gregori, B.; Bonomi, F.; J. Agric. Food Chem. 1995, 43, 53.

6. Iametti, S.; De Gregori, B.; Vecchio, G.; Bonomi, F.; Eur. J. Biochem. 1996, 237, 106.

7. Relkin, P.; Int. J. Biol. Macromol. 1998, 22, 59.

8. Shim, J.; Mulvaney, S. J.; J. Sci. Food Agric. 2001, 81, 706.

9. Standing, M.; Hermansson, A.-M.; Food Hydrocolloids 1990 , 4, 121.

10. Renard, D.; Lefebvre, J.; Int. J. Biol. Macromol. 1992, 14, 287.

11. Alonso, D. O. V.; Dill, K. A.; Biochemistry 1991, 30, 5974. 
12. Shimada, K.; Cheftel, J. C.; J. Agric. Food Chem. 1988, 36, 1018.

13. de Bont, P. W.; van Kempen, G. M. P.; Vreeker, R.; Food Hydrocolloids 2002, 16, 127.

14. Gonçalves, M. P.; Torres, D.; Andrade, C. T.; Azero, E. G.; Lefèbvre, J.; Food Hydrocolloids 2004, 18, 181.

15. Ravindra, P.; Genovese, D. B.; Foegeding, E. A.; Rao, M. A.; Food Hydrocolloids 2004, 18, 775.
16. Cox, W. P.; Merz, E. H.; J. Polymer Sci. 1958, $28,619$.

17. Olsson, C.; Langton, M.; Hermansson, A.-M.; Food Hydrocolloids 2002, 16, 111.

Received: July, 27, 2006 Web Release Date: October 19, 2006 